\title{
Efektivitas Pembelajaran Daring di Masa Pandemi Covid-19
}

\author{
Aas Aliana Futriani Hidayah ${ }^{1}$, Robiah Al Adawiyah ${ }^{2}$, Prima Ayu Rizqi Mahanani ${ }^{3}$ \\ ${ }^{1}$ Program Studi Ahwal Al-Syakhsiyyah, IAIN Kediri, Jl. Sunan Ampel No.7, Kediri, 64127 \\ E-mail: alianaaaz@gmail.com \\ ${ }^{2}$ Program Studi Pendidikan Agama Islam, IAIN Kediri, Jl. Sunan Ampel No.7, Kediri, 64127 \\ E-mail: robiah221098@gmail.com \\ ${ }^{3}$ Program Studi Komunikasi dan Penyiaran Islam, IAIN Kediri, Jl. Sunan Ampel No.7, Kediri, 64127 \\ E-mail: prima.ayu99@yahoo.com
}

\begin{abstract}
The Covid-19 pandemic that occurred in Indonesia made many changes in various sectors. The education sector is no exception, which is forced to change the learning system, which was originally face-to-face in schools, must be replaced with an online learning system. Even though technological developments have progressed, in reality the mastery of information and communication technology has not been mastered properly. Those who are involved in online learning also feel that they have not been able to implement it optimally. There are many obstacles and difficulties experienced by educators, students, and parents when implementing online learning. This study aims to determine the effectiveness of online learning during the Covid-19 pandemic in in Beji Hamlet, Sawiji Village, Jogoroto District, Jombang Regency. The result is that learning with online media is possible to be effective for students who are in areas where internet access is smooth, the facilities and infrastructure are supportive, and are not technologically illiterate.
\end{abstract}

Keywords—: Effectiveness; Online Learning; Covid-19 Pandemic.

\section{PENDAHULUAN}

Pandemi Covid-19 yang melanda hampir seluruh negara di belahan dunia --termasuk Indonesia--menjadi topik yang mendominasi pembicaraan publik. Hal ini dikarenakan pemberitaannya yang massif di berbagai media, baik cetak, elektronik, maupun online. Dalam waktu singkat, namanya mampu mengalihkan perhatian publik. Pasalnya, Covid-19 adalah penyakit menular yang dapat menyebar, baik secara langsung ketika berinteraksi dengan orang yang membawa virus Korona (droplet, permukaan yang terkontaminasi, limbah manusia) maupun tidak langsung (udara). Penyakit ini menyerang --terutama pada-sistem pernapasan (paru-paru) dan belum ditemukan obatnya. Salah satu cara memutus mata rantai penyebaran Covid-19 dengan menaati protokol kesehatan, seperti: rajin cuci tangan dengan sabun dan air mengalir, memakai masker atau face shield, menjaga jarak sosial, menghindari tempat-tempat keramaian serta ruangan sempit dan tertutup yang ventilasi udaranya buruk.

Salah satu protokol kesehatan yang dianggap berakibat pada terhambatnya laju perkembangan dan pertumbuhan berbagai bidang kehidupan adalah jaga jarak (physical distancing). Salah satu sektor yang signifikan terdampak Korona adalah pendidikan beserta elemen-elemennya. Alasan ini berdasarkan analisis pakar bahwa sekolah yang biasanya digunakan untuk berinteraksi oleh pendidik dan peserta didik dinilai menjadi tempat yang berisiko tinggi dalam penularan Covid-19. Oleh karena itu, pemerintah memindahkan proses belajar-mengajar di sekolah menjadi di rumah.

Istilah populer dari kebijakan tersebut adalah school from home bagi siswa dan work from home bagi guru. Pembelajaran daring dipilih sebagai salah satu cara untuk mengurangi potensi penyebaran Korona. Pembelajaran daring yang dimaksudkan dalam penelitian ini adalah pembelajaran yang menggunakan media-media yang terkoneksi dengan internet. Media pembelajaran ini merupakan perantara penyampaian pembelajaran dari pendidik ke peserta didik.

Media pembelajaran yang baik adalah media yang memungkinkan tersampaikannya maksud dan tujuan materi pembelajaran secara maksimal. Menurut Wina Sanjaya, pemilihan media pembelajaran dapat didasarkan pada beberapa prinsip, yaitu (1) tujuan yang akan dicapai, baik kognitif, afektif dan psikomotorik; (2) adanya konsep yang jelas untuk menunjang efektivitas dan efisiensi proses pembelajaran; (3) karakteristik peserta didik; (4) sesuai dengan gaya belajar peserta didik dan kemampuan pendidik; (5) kondisi lingkungan.

Para pendidik yang melaksanakan pembelajaran daring dengan memanfaatkan teknologi informasi dan komunikasi bertujuan untuk memudahkan interaksi antara guru dan peserta didik. Kemudahan dalam mengaksesnya diharapkan bisa menjaga kualitas pendidikan selama pandemi. Penggunaan media daring atau platform belajar dinilai bisa menjadi solusi agar peserta didik tetap bisa mengikuti proses belajar-mengajar di jenjang manapun, baik PAUD, sekolah dasar, sekolah menengah pertama, sekolah menengah atas, dan perguruan tinggi. Akan tetapi, cara ini dalam pelaksanaannya mengalami banyak kendala terkait dengan efektivitas proses belajar-mengajarnya.

Proses pembelajaran yang membutuhkan hubungan timbal balik antara pendidik dan peserta didik di dalam kelas menjadi difasilitasi oleh media daring, diantaranya youtube, whatsapp, google classroom, zoom, meet, quizzes, edmodo, e-learning dan schoology. Penyampaian materi melalui kelas-kelas virtual cenderung mempengaruhi perkembangan dan keaktifan peserta didik selama proses pembelajaran. Berdasarkan pengamatan awal, peserta didik hanya menerima materi dan tugas-tugas tanpa ada 
pendampingan dari pendidik yang seharusnya juga dilakukan meskipun melalui daring. Oleh karena itu, praktik pembelajaran daring perlu evaluasi agar ada perbaikan-perbaikan demi terselenggaranya proses belajar yang efektif. Penelitian ini berusaha untuk mengetahui efektivitas pelaksanaan pembelajaran daring di wilayah pedesaan, yaitu di Dusun Beji, Desa Sawiji, Kecamatan Jogoroto, Kabupaten Jombang.

\section{METODE PENELITIAN}

Pendekatan yang digunakan dalam penelitian ini adalah pendekatan kualitatif. Sumber data primer didapatkan dari para peserta didik yang tinggal di Dusun Beji, Desa Sawiji, Kecamatan Jogoroto, Kabupaten Jombang. Data sekunder berupa bukubuku referensi yang berkaitan dengan efektivitas pembelajaran daring. Data dikumpulkan dengan menggunakan teknik observasi, wawancara, dan pengisian kuisioner. Pengisian kuisioner dilakukan untuk mempermudah penggalian data di masa pandemi yang tidak memungkinkan berinteraksi secara langsung dengan informan. Data dianalisis secara deskriptif yang menggambarkan keefektifan pembelajaran daring berdasarkan kriteria tujuan pendidikan dengan tahapan dari pengumpulan data, reduksi data, hingga penyajian data.

\section{III.HASIL DAN PEMBAHASAN}

\section{A. Pembelajaran Daring di Masa Pandemi Covid-19}

Munculnya permasalahan baru di bidang pendidikan dilatarbelakangi oleh wabah Korona yang menyebar hampir di seluruh negara di dunia, tidak terkecuali Indonesia. Penyebarannya yang masif berdampak pada kegiatan belajar-mengajar sejak dikeluarkannya Surat Edaran dari Menteri Pendidikan dan Kebudayaan Nomor 36962/MPK.A/HK/2020 tanggal 13 Maret 2020 terkait pembelajaran secara daring dan bekerja dari rumah dalam rangka pencegahan Corona Virus Disease (COVID-19). Surat edaran tersebut merupakan respon pendidikan dalam menyikapi pandemi Covid-19. Sejak surat edaran dikeluarkan, proses pembelajaran di kelas dialihkan pada pembelajaran daring yang biasa kita sebut dengan school from home.

Pembelajaran daring adalah proses pembelajaran yang menggunakan akses komputer dan jaringan internet untuk membantu proses interaksi dalam proses pembelajaran (Tesniyadi, 2018). Pendidik dan peserta didik dapat melangsungkan kegiatan belajar-mengajar tanpa harus bertatap muka secara langsung untuk mencegah penyebaran virus Korona. Pembelajaran daring bertujuan memberikan layanan pembelajaran bermutu dalam jaringan yang bersifat masif dan terbuka untuk menjangkau peminat yang lebih banyak dan lebih luas (Adhe \& Kartika, 2018). Pembelajaran daring memerlukan dukungan perangkatperangkat mobile yang mumpuni, yang dapat digunakan untuk mengakses informasi kapan saja dan di mana saja. Pada titik ini, penggunaan internet memberikan banyak sumbangan di bidang pendidikan, termasuk terlaksananya proses pembelajaran jarak jauh.

Pembelajaran yang dilakukan dengan menggunakan sistem online menjadikan materi pelajaran dapat tercapai dengan lebih mudah dan lebih luas oleh peserta didik. Hal tersebut memudahkan pendidik maupun peserta didik untuk tetap mengajar dan belajar meskipun sedang melakukan sosial jarak yang sesuai dengan anjuran dari pemerintah. Akan tetapi, pengalihan kegiatan belajar-mengajar secara daring memberikan kendala tersendiri, baik bagi pendidik maupun peserta didik, mulai dari bahan ajar hingga media pembelajaran yang digunakan. Pendidik dituntut agar proses pembelajaran berjalan sebagaimana mestinya sedangkan peserta didik tidak sedikit yang terbatas pada tersedianya sarana pendidikan daring.

\section{B. Efektivitas Pembelajaran dalam Jaringan}

Efektivitas atau keefektifan dalam KBBI berarti keadaan berpengaruh, hal berkesan, keberhasilan tentang usaha atau tindakan. Efektivitas merupakan hubungan antara keluaran suatu pusat tanggung jawab dengan sasaran yang mesti dicapai, semakin besar kontribusi daripada keluaran yang dihasilkan terhadap nilai pencapaian sasaran tersebut, maka dapat dikatakan efektif (Supriyono, 2000: 29). Menurut Gibson, efektivitas adalah penilaian yang dibuat sehubungan dengan prestasi individu, kelompok, dan organisasi. Semakin dekat prestasi mereka terhadap prestasi yang diharapkan maka dinilai semakin efektif (Putri, 2019: 1).

Efektivitas pembelajaran adalah proses pembelajaran yang dilakukan oleh guru untuk mengubah kemampuan dan persepsi siswa dari yang sulit mempelajari sesuatu menjadi mudah mempelajarinya. Keefektifan program pembelajaran tidak hanya ditinjau dari segi tingkat prestasi belajar saja, melainkan harus pula ditinjau dari segi proses dan sarana penunjang. Efektivitas metode pembelajaran merupakan suatu ukuran yang berhubungan dengan tingkat keberhasilan dari suatu proses pembelajaran. Keefektifan dapat diukur dengan melihat minat peserta didik terhadap kegiatan pembelajaran.

Dalam konteks kegiatan pembelajaran, perlu dipertimbangkan efektivitas artinya sejauhmana tujuan yang telah ditetapkan dapat dicapai sesuai harapan. Ciri-ciri keefektifan program pembelajaran adalah berhasil mengantarkan siswa mencapai tujuantujuan instruksional yang telah ditentukan, memberikan pengalaman belajar yang atraktif, melibatkan siswa secara aktif, sehingga menunjang pencapaian tujuan instruksional dan memiliki sarana-sarana yang menunjang proses belajar-mengajar (Rohmawati, 2015).

Indikator sesuatu bisa dikatakan efektif apabila mencapai sasaran yang diinginkan, baik dari segi tujuan pembelajaran maupun prestasi siswa yang maksimal. Beberapa indikator keefektifan pembelajaran adalah ketercapaian ketuntasan belajar, ketercapaian keefektifan aktivitas siswa (yaitu pencapaian waktu ideal yang digunakan siswa untuk melakukan setiap kegiatan yang termuat dalam rencana pembelajaran), ketercapaian efektivitas kemampuan guru mengelola pembelajaran dan respon 
siswa terhadap pembelajaran yang positif (Sinambela, 2006: 78). Pada konteks ini, efektivitas pembelajaran merupakan suatu ukuran keberhasilan dari proses interaksi dalam situasi edukatif untuk mencapai tujuan pembelajaran. Dengan demikian, kegiatan belajar mengajar harus senantiasa ditingkatkan efektivitasnya demi meningkatkan mutu dari pada pendidikan itu sendiri. Seorang guru harus pandai dalam memilih metode apa yang sebaiknya digunakan agar dapat ditangkap oleh siswa dari apa yang disampaikan.

\section{Praktik Pembelajaran Daring di Dusun Beji}

Beji adalah dusun yang terletak di Desa Sawiji, Kecamatan Jogoroto, Kabupaten Jombang. Di Dusun Beji ada beberapa lembaga pendidikan, baik di tingkat dasar maupun tingkat menengah, antara lain: SDN 1 Beji, SDIT Beji, dan MTs Darul Hikmah Beji. Sekolah-sekolah yang ada di Dusun Beji tersebut juga terdampak oleh Korona dengan diterapkannya pembelajaran daring. Adanya kebijakan melaksanakan pembelajaran di rumah maka pihak sekolah pun harus menaatinya, meskipun pada kenyataannya masih belum siap dan belum maksimal dalam praktiknya.

Perpindahan sistem belajar konvensional ke sistem daring sangat mendadak tanpa adanya persiapan yang matang sehingga banyak kendala yang dijumpai. Ketidaksiapan pendidik, peserta didik, serta orang tua terhadap pembelajaran daring menjadi kunci utama permasalahan yang terjadi dalam kegiatan belajar-mengajar di Dusun Beji. Dari kuisioner yang dijawab oleh peserta didik di Dusun Beji, Desa Sawiji, Kecamatan Jogoroto, Kabupaten Jombang, diketahui pembelajaran daring yang sedang dilakukan di rumah masing-masing siswa dirasakan belum efektif. Berikut ini adalah masalah-masalah yang ditemukan oleh peneliti, antara lain:

\section{Keluhan Pemberian Tugas dan Kesulitan Memahami Materi Pelajaran}

Pada awal pelaksanaan pembelajaran daring, orang tua peserta didik setuju dan antusias ikut serta dalam praktiknya. Setelah beberapa hari melaksanakan pembelajaran daring, keluhan dari pihak orang tua mulai bermunculan, terutama perihal pembagian waktu antara mendampingi anak untuk sekolah daring dan pekerjaan rumah yang harus diselesaikan serta harus mencari nafkah (bekerja). Pemberian tugas kepada siswa untuk dikerjakan di rumah selama libur pandemi Covid-19 menjadi keluhan peserta didik dan juga orang tua yang disebabkan tugas pekerjaan rumah terlalu banyak.

Peserta didik merasa tertekan karena banyaknya soal yang harus dikerjakan dan terkadang harus diselesaikan hingga larut malam. Ada siswa yang dijumpai peneliti mengalami gangguan kesehatan, seperti pusing, demam, dan sakit perut. Pada titik ini, pemberian tugas dirasakan oleh peserta didik belum efektif karena mereka masih kesulitan dalam memahami materi yang disampaikan guru. Kekurangpahaman dalam mencerna materi pelajaran membuat siswa panik ketika mengerjakan soal-soal dan akibatnya tidak bisa menahan emosi (marah-marah). Ketika Belajar di rumah pun, ada sebagian siswa yang suasana di rumahnya tidak kondusif karena tidak ada pendampingan dari orang tua.

\section{Gangguan Jaringan Internet}

Jaringan internet yang kurang lancar dapat menghambat berlangsungnya pembelajaran daring, seperti yang dirasakan oleh peserta didik di Dusun Beji. Hal ini disebabkan karena letak rumah mereka yang berada di daerah pedesaan sehingga sering sekali terjadi gangguan pada jaringan internet. Hal ini merupakan tantangan tersendiri dalam penerapan pembelajaran daring karena syarat utama terlaksananya pembelajaran daring adalah adanya jaringan internet.

Akibat jaringan internet yang tidak lancer, peserta didik kurang memahami instruksi yang diberikan guru karena informasi yang didapatkan peserta didik tidak lengkap dan kurang jelas. Ketika guru menjelaskan, suara menjadi tidak lancar dan informasi yang diterima tidak lengkap sehingga peserta didik sulit untuk memahami materi yang disampaikan. Jaringan internet yang kurang stabil dapat menghambat proses pembelajaran daring karena internet memiliki peranan yang penting dalam menunjang kelancaran pembelajaran jarak jauh. Keadaan ini sesuai dengan pernyataan Rosenberg mengenai kriteria dasar dalam e-learning atau pembelajaran daring, yaitu adanya penyampaian yang dikirimkan kepada pengguna (peserta didik) melalui komputer dengan menggunakan standart teknologi internet (Yodha, 2019).

\section{Merasa Jenuh}

Kejenuhan belajar juga terjadi karena kegiatan yang selalu sama dan monoton sehingga siswa merasa bosan selama pembelajaran daring. Guru yang masih kesulitan dalam mengaplikasikan teknologi hanya menggunakan media pembelajaran daring melalui whatsapp atau google form sehingga dinilai siswa kurang bervariasi. Intonasi suara ketika guru menyampaikan materi juga tidak bisa dinamis karena tidak dapat berinteraksi secara langsung. Oleh karena itu, pembelajaran daring yang menggunakan aplikasi terbatas menyebabkan siswa merasa malas, ditambah banyaknya tugas yang diberikan dan minim penjelasan serta penguatan dari guru.

Situasi pandemi yang mengharuskan untuk tetap di rumah saja semakin memicu kejenuhan peserta didik dalam belajar. Kejenuhan belajar terjadi karena tuntutan kepada peserta didik untuk selalu mematuhi aturan pemberian tugas-tugas. Efek kejenuhan yang muncul dari siswa yang mengalami pembelajaran daring adalah cepat marah, malas, dan mudah frustasi. Dalam kasus ini, peserta didik mengatakan kalau mereka merasa bosan dan jenuh dengan pembelajaran daring. Ketika mereka disuruh memilih antara pembelajaran daring atau luring, mereka kompak memilih pembelajaran luring. 
Website : http://sosial.unmermadiun.ac.id/index.php/sosial

\section{Keterbatasan Penguasaan Teknologi dan Tersedianya Kuota Internet}

Tantangan yang dihadapi oleh peserta didik yang menjadi informan penelitian ini adalah tidak terlalu menguasai teknologi, sehingga mereka merasa kesulitan dalam mengoperasionalkan smartphone-nya ketika pembelajaran daring. Teknologi di saat kondisi pandemi memiliki peranan penting dalam keberlangsungan pembelajaran daring sehingga menuntut kesiapan dari peserta didik khususnya. Orang tua juga ada yang tidak paham dengan pembelajaran daring yang dilaksanakan oleh anaknya.

Selain itu, keterbatasan persoalan biaya dalam penyediaan kuota internet menjadi masalah utama bagi siswa. Hal ini dikarenakan mayoritas warga desa yang menganggap dirinya adalah golongan bawah. Borosnya penggunaan kuota internet menjadi keluhan orang tua peserta didik. Orang tua merasa keberatan karena tidak mampu untuk membelikan kuota internet secara terus-menerus untuk kebutuhan sekolah daring. Bagi orang tua yang tidak bisa bekerja rutin selama wabah Korona terjadi menilai kuota internet menjadi barang mewah karena tidak adanya pemasukan keuangan. Penggunaan smartphone yang hanya satu dan harus digunakan secara bergantian dengan anggota keluarga lainnya yang juga sekolah daring menjadi kendala yang signifikan juga.

\section{IV.KESIMPULAN}

Perkembangan teknologi memiliki pengaruh signifikan terhadap proses pengajaran dan pembelajaran dalam jaringan (daring). Para pendidik yang memanfaaatkannya untuk mempermudah proses belajar-mengajar selama pandemi menemui banyak kendala dan hambatan dalam praktiknya. Efektivitas pembelajaran daring yang dilaksanakan oleh lembaga-lembaga pendidikan di Dusun Beji, Desa Sawiji, Kecamatan Jogoroto, Kabupaten Jombang bisa dikatakan belum berjalan efektif. Kendala yang dirasakan oleh peserta didik beserta orang tua atau walinya meliputi pemahaman materi yang kurang karena pendidik hanya memberikan penugasan, gangguan jaringan internet, adanya kejenuhan, keterbatasan penguasaan teknologi, keterbatasan sarana prasarana dan biaya kuota internet. Oleh karena itu, komponen-komponen pendukung dalam pembelajaran daring perlu dilengkapi terlebih dahulu, kemampuan yang belum memadai dari peserta didik dan orang tua atau wali dalam mengoperasionalkan teknologi informasi dan komunikasi perlu ditingkatkan, serta evaluasi berkala perlu dilakukan agar pembelajaran daring bisa lebih efektif.

\section{UCAPAN TERIMA KASIH}

Ucapan terima kasih disampaikan kepada semua pihak yang telah berkontribusi dalam penelitian ini, khususnya pihak perangkat Desa Beji, dosen pembimbing penelitian, orang tua, dan teman-teman yang ikut berpartisipasi dalam penelitian ini sehingga dapat terlaksana dengan lancar.

\section{VI.DAFTAR PUSTAKA}

Putri, U. H. (2019). Efektivitas dan Efisiensi Pembiayaan Pendidikan”. Padang: Universitas Negeri Padang.

Rohmawati, A. (2015). Efektivitas Pembelajaran. Jurnal Pendidikan Usia Dini.

Setiawan, R. (2020). Membangun Efektivitas Pembelajaran Sosiologi di Tengah Pandemi Covid-19. Jurnal Ilmiah Penelitian Pendidikan dan Sosiologi. Volume 4, Nomor 1, Mei dalam https://ejournal.uindiksha.ac.id/. Diakses 9 Agustus 2020.

Supriyono. (2000). Sistem Pengendalian Manajemen. Semarang: Universitas Diponegoro

Tesniyadi. (2018). Pengelolaan Pendidikan. Yogyakarta: Samudera Biru.

Yodha, S. A. (2019). Persepsi Mahasiswa Terhadap Pelaksanaan E-Learning dalam Mata Kuliah Manajemen Sistem Informasi Mahasiswa Jurusan Teknologi Pendidikan Universitas Negeri Malang. Jurnal Kajian Teknologi Pendidikan. Volume 2, No. 3. 